Iwona Janowska

Uniwersytet Jagielloński

iwona.janowska@uj.edu.pl

Marta Bodzioch

Uniwersytet Jagielloński

mrt.bodzioch@gmail.com

\title{
TRENING AKULTURACYJNY A ROZWIJANIE INTERKULTUROWEJ KOMPETENCJI KOMUNIKACYJNEJ
}

\begin{abstract}
Accultural training and developing the intercultural communication skills

The article introduces the concept of language lessons based on an accultural training model in a type of a simulation that was presented in a reaction to the current inquires on the role of culture in glottodydactics. The goal of such lessons is to develop students' intercultural communication skills through the task-solving method. The central point of the article is the author's personal lessons conducted via a training script.
\end{abstract}

Keywords: cultural syndromes, accultural training, simulation, intercultural skills, communication skills

Słowa kluczowe: syndromy kulturowe, trening akulturacyjny, symulacja, kompetencje międzykulturowe, kompetencja komunikacyjna

\section{Wprowadzenie}

Współczesne społeczeństwa to społeczeństwa wielokulturowe. Nie występują już dzisiaj grupy homogeniczne, które nie miałyby kontaktów z innymi lub których członkowie nie utrzymywaliby żadnych więzi z innymi narodami. Wiele 
społeczności powstało wskutek napływu migrantów, mieszania się populacji, wspólnego zamieszkiwania i asymilacji sposobów życia, rytuałów i systemów wartości.

Na poziomie europejskim interkulturowość stanowi ważny wymiar w budowaniu obywatelstwa i zbiorowej tożsamości. Mobilność geograficzna i kontakty są podstawowymi elementami konstruowania tej przestrzeni. Dlatego też instytucje polityczne i edukacyjne tworzą programy, metody i techniki nauczania, które mają na celu polepszenie wzajemnego poznania się oraz zrozumienia, i które zmierzają do zmiany relacji międzyludzkich z wielokulturowych na interkulturowe.

Celem artykułu jest prezentacja koncepcji zajęć językowych wykorzystujących model treningu międzykulturowego w typie symulacji, które zostaną przedstawione na tle współczesnych dociekań na temat roli kultury w glottodydaktyce. W pierwszej części tekstu wyjaśniamy kluczowe terminy, m.in. syndromy kulturowe, trening akulturacyjny oraz metoda symulacji w perspektywie zadaniowej. Następnie przedstawiamy koncepcję zajęć językowych umożliwiających rozwój międzykulturowych kompetencji komunikacyjnych uczących się. Ostatnim punktem jest prezentacja autorskiego scenariusza lekcji w typie treningu.

\section{Interkulturowość i podejście interkulturowe}

Interkulturowość jest definiowana jako dynamiczny proces wymiany między różnymi kulturami. Tak rozumiana stanowi pojęcie stosunkowo nowe. Natomiast jeśli chodzi o jej obiektywną obecność w społeczeństwie, stanowi już fakt. Ludzie zawsze byli członkami różnorodnych grup kulturowych, ich spotkania i mieszanie się odbywało się za pośrednictwem handlu, podboju lub kolonizacji. Termin interkulturowość otwiera nową perspektywę „krzyżujących się spojrzeń". Jeśli istnieje różnica kulturowa, nie jest już ona postrzegana jako zagrożenie, lecz jako wzajemne wzbogacenie kulturowe. O interkulturowości możemy mówić wówczas, gdy ma miejsce wymiana, spotkanie i podział. Nie jest ona treścią nauczania, ale raczej działaniem mającym na celu tworzenie pomostów i więzi między kulturami. W odróżnieniu od wielokulturowości, która implikuje istnienie mozaiki kultur, interkulturowość jest dynamiczna, to proces akceptacji i zrozumienia tożsamości kulturowych. Podejście interkulturowe oznacza więc wyjście poza proste zrozumienie innej grupy kulturowej i budowanie pomostów między kulturami w celu wymiany i wzajemnego ubogacenia się (Chavez, Favier i Pélissier, 2012: 12).

Włączenie takiego podejścia do szkolnego i pozaszkolnego procesu edukacyjnego stało się koniecznością. Refleksja na temat wyobrażeń dotyczących „drugiego", na temat spotkania się z innością i uświadomienie sobie faktu, że wszyscy jesteśmy narażeni na upraszczający, stereotypowy sposób myślenia, pozwala na wykształcenie obiektywnego spojrzenia, bardziej świadomego drugiego 
człowieka. Podejście interkulturowe oraz powstałe w jego obrębie metody $\mathrm{i}$ techniki nauczania pobudzają do refleksji nad samym sobą, nad własną przynależnością, nad systemami wartości. Jego celem jest tworzenie tożsamości w relacji z odmiennością; z jednej strony chodzi o to, by zaakceptować różnorodność spojrzeń, by spotkać się z innymi punktami widzenia i zrozumieć różne sposoby życia, z drugiej zaś - uświadomić sobie, że nie jesteśmy uwarunkowani przynależnością do jednej kultury.

\section{Podejście interkulturowe w dydaktyce języków obcych}

Podejście interkulturowe pojawiło się w latach 70. XX wieku w kontekście migracji europejskich i związanym z tym kształceniem dzieci imigrantów. Prace prowadzone przez Radę Europy w dziedzinie migracji i edukacji przyczyniły się do ukształtowania polityki umożliwiającej uznanie różnorodności kulturowej jako swego rodzaju bogactwa, a nie jako zagrożenia czy trudności. Wtedy to interkulturowość wyszła z obszaru migracyjnego. Zaczęto ją postrzegać jako świadome działanie pedagogiczne, mające na celu umożliwienie uczącym się odejście od monolitycznej wizji kultury i akceptację wielo- i różnokulturowości (Chavez, Favier i Pélissier, 2012: 15).

Rada Europy wspiera politykę edukacyjną i językową, mającą na celu wzajemne zrozumienie i tolerancję w różnojęzycznej i różnokulturowej Europie. Ta polityka, wyrażona w Europejskim Systemie Opisu Kształcenia Językowego (2003), promuje uczenie się oraz poznawanie wielu języków i kultur. Publikacja ta naznaczyła w zasadniczy sposób dydaktykę języków obcych. Od momentu ukazania się ma ona wpływ na całokształt procesu uczenia się, nauczania i ewaluacji w europejskich systemach edukacyjnych, ale także poza Europą.

ESOKJ proponuje wizję komunikacji jako działania: mówić, pisać, czytać i słuchać znaczy działać. Stąd zrodziło się pojęcie podejścia ukierunkowanego na działanie (action-oriented approach). W ramach tej perspektywy uczący się/użytkownik języka realizuje zadania językowe, które odwołują się do wielu kompetencji (językowych kompetencji komunikacyjnych i kompetencji ogólnych) i uruchamiają działania językowe.

Autorzy ESOKJ nawiązują do podejścia interkulturowego od pierwszych stron dokumentu i postrzegają je jako to, które przyczynia się bezpośrednio do planowanego rozwoju osobistego uczącego się: „Według definicji interkulturowości najważniejszym celem edukacji językowej jest wspieranie rozwoju osobowości uczącego się, jego poczucia tożsamości, przez doświadczenie bogactwa innych języków i kultur" (ESOKJ, 2003: 13).

Według ESOKJ uczyć się języka znaczy nabywać kompetencje komunikacyjne i kompetencje ogólne, które mogą być ukierunkowane na perspektywę 
interkulturową. Cztery typy kompetencji łączą się bezpośrednio z interkulturową kompetencją komunikacyjną:

- savoir: wiedza pochodząca z „krzyżowania się spojrzeń”;

- savoir-être: postawy, czyli relatywizowanie swojego systemu odniesień kulturowych, otwarcie się na inność, wyjście z centrum uwagi;

- savoir-faire: zdolność do nawiązywania kontaktów i relacji między kulturami, odgrywanie roli pośrednika kulturowego, rozwiązywanie nieporozumień kulturowych, zdolność do refleksji na temat własnej kultury itp.;

- savoir-apprendre: mobilizacja nabytej wiedzy w celu odkrywania nowych doświadczeń, zachowań, systemów wartości i wierzeń.

W ESOKJ wyodrębniono, obok wrażliwości interkulturowej, wiedzy socjokulturowej oraz wiedzy o świecie, umiejętności interkulturowe i przypisano je do obszaru umiejętności praktycznych. Dokument sytuuje je w polu wiedzy proceduralnej kompetencji ogólnych, które, w przeciwieństwie do kompetencji deklaratywnych, nie polegają na zdobyciu wiedzy, lecz łączą się bezpośrednio z umiejętnościami umożliwiającymi uczącemu się skuteczne działanie. Umiejętności interkulturowe to: „umiejętność dostrzegania związku między kulturą własną a obcą, wrażliwość kulturowa oraz umiejętność dokonywania wyborów strategii i ich odpowiedniego użycia w kontakcie z osobami z innych kultur, umiejętność pośredniczenia między kulturą własną a kulturą obcą oraz radzenia sobie $z$ interkulturowymi nieporozumieniami i wynikającymi stąd sytuacjami konfliktowymi, umiejętność przezwyciężania stereotypów" (ESOKJ, 2003: 96). Stanowią one trzon interkulturowej kompetencji komunikacyjnej, której rozwój jest jednym z zasadniczych celów kształcenia językowego.

\section{Charakter praktyczny umiejętności interkulturowych}

Rozwój interkulturowej kompetencji komunikacyjnej rozumiemy jako przekazywanie umiejętności praktycznych osobie uczącej się języka obcego, co pozwala jej na szybkie odnalezienie się w przestrzeni odmiennej językowo, kulturowo i społecznie. Efektem tego ma być postawa otwartości na różnorodność kulturową oraz pozyskanie umiejętności analizy i interpretacji zachowań rodzimych użytkowników języka docelowego, innych niż zachowania osoby uczącej się. Dla takiego spojrzenia kluczowy jest aktywny udział w odpowiednio przygotowanych zajęciach o charakterze działania praktycznego. Idea ta wynika z przekonania, że przekazywanie wiedzy teoretycznej na dany temat nie warunkuje umiejętności zastosowania tej wiedzy w praktyce.

Jak już wspomniano, kompetencja interkulturowa nie jest tożsama $z$ wiedzą historyczną, geograficzną, realiami życia ani z kulturą dnia codziennego. Najważniejsze są różnice w uwarunkowanych kulturowo formach zachowania 
wynikające z czynników psychologiczno-społecznych. Ich właściwa identyfikacja, umiejętność odczytania i stosowania łączą się z orientacją w syndromach kulturowych, czyli układzie „wspólnych postaw, przekonań, kategoryzacji, definicji, norm, wartości, zorganizowanych wokół szczególnego tematu, który może być zidentyfikowany przez ludzi używających określonego języka, w określonym okresie historycznym, w określonym regionie geograficznym" (Strelau i Doliński, 2004: 454). Czynniki te mają kluczowy wpływ na kształt, przebieg i poziom komunikacji pomiędzy przedstawicielami różnych kręgów i

grup. Świadomość znaczenia syndromów kulturowych (lub jej brak) decyduje o jakości i skuteczności procesu komunikacji interpersonalnej. Syndromy kulturowe to dla niniejszego tekstu pojęcie kluczowe.

Biorąc pod uwagę treści i zalecenia ESOKJ, należy postawić pytanie: w jaki sposób rozwijać kompetencje interkulturowe uczących się $w$ ujęciu działaniowym? Niestety, w obrębie glottodydaktyki brakuje gotowych rozwiązań. Propozycję wypełnienia tej luki dydaktycznej może stanowić zwrócenie się w stronę psychologii międzykulturowej i oferowanych na jej gruncie innowacyjnych technik.

\section{Psychologia międzykulturowa: trening akulturacyjny i metoda symulacji}

Przedmiotem zainteresowania psychologii międzykulturowej jest „badanie podobieństw i różnic $w$ indywidualnym funkcjonowaniu ludzi należących do różnych grup kulturowych i etniczno-kulturowych, badanie relacji między czynnikami psychologicznymi, społeczno-kulturowymi i biologicznymi oraz badanie zmian zachodzących w zakresie tych czynników" (Strelau i Doliński, 2004: 451). Obserwacje i wnioski psychologii międzykulturowej w tej materii pozwoliły na zdefiniowanie technik pracy z grupą wielokulturową, mających na celu rozwój kompetencji interkulturowej uczestników. Autorki ${ }^{1}$ książki Warsztaty kompetencji międzykulturowych - podręcznik dla trenerów (Lipińska, 2008), skierowanej do twórców warsztatów kompetencji kulturowych, posługują się definicją szkolenia rozumianego jako działanie mające na celu zdobycie wiedzy lub umiejętności. Badaczki wyróżniają trzy formy szkoleń: akademicką, warsztatową oraz treningową (tamże: 10).

$\mathrm{Na}$ uwagę zasługuje tu forma treningu akulturacyjnego opartego na technice symulacji, rozumianej jako metoda mająca na celu wytworzenie sztucznej sytuacji krytycznej, podczas której uczestnicy muszą dokonać konkretnych wyborów, zdecydować się na pewne zachowania, a następnie zaobserwować, jakie efekty niosą ze sobą te decyzje w komunikacji z innymi (tamże: 11-12). W definicji Boskiego (2010: 567) celem nadrzędnym tego rodzaju

${ }^{1}$ Kinga Białek, Anna Kawalska, Ewa Kownacka i Marta Piegat-Kaczmarczyk. 
treningu jest „przekraczanie etnocentrycznych wizji świata”, natomiast według Grzymały-Moszczyńskiej (2004: 177) to „pomoc w psychologicznym i społecznym funkcjonowaniu osobom przenoszącym się z jednej kultury do drugiej, w taki sposób, aby w nowej kulturze poziom tego funkcjonowania był zbliżony do poziomu efektywności, jaki przeżywali oni w warunkach kultury macierzystej". Elementem wspólnym w tych definicji jest trwała zmiana postaw uczestników wobec odmienności kulturowej czy nietolerancji, z jaką stykają się oni podczas wykonywania zadania treningowego.

Na gruncie glottodydaktyki spotykamy różne spojrzenia na definicje symulacji. Siek-Piskozub rozumie to pojęcie jako oznaczające jedną z technik ludycznych. Symulacja kojarzona jest tu z techniką teatralną, dramą z elementami dyskusji grupowej i została usytuowana obok gry i zabawy (Siek-Piskozub, 1995: 26). W ujęciu psychologii międzykulturowej symulacje określa się mianem zadania egzystencjalnego, które w odróżnieniu od przywołanych technik ludycznych różni się stopniem zaangażowania emocjonalnego. Techniki teatralne narzucają uczącym się role fikcyjnych postaci będących w określonej sytuacji - inaczej jest w symulacji rozumianej według definicji psychologicznej, gdzie otrzymują oni jedynie wytyczne do wykonania pewnego zadania, podczas którego zachowują się zgodnie ze swoim osobistym doświadczeniem i wiedzą (Lipińska, 2008: 12). Aspekt emocjonalny ma swoje źródło w uświadomieniu uczestnikom symulacji towarzyszących im w trakcie treningu emocji oraz ich wpływu na porozumienie pomiędzy przedstawicielami odmiennych kultur. Podczas pracy z emocjami konieczne jest dokładne omówienie i interpretacja, które pozwolą uczestnikom na ich przepracowanie, a także zrozumienie szerszego kontekstu wykonanego zadania, np. w dyskusji lub pracy grupowej. Jest to niezwykle istotny i konieczny element, na który prowadzący trening powinien przeznaczyć odpowiednią ilość czasu (Grzymała-Moszczyńska, 2004: 183). W niniejszym tekście przyjmujemy psychologiczną definicję symulacji.

\section{Zadanie - definicje ESOKJ a psychologia międzykulturowa}

Według ESOKJ (2003: 21) zadaniem jest „każde celowe działanie, uważane za konieczne, by rozwiązać jakiś problem, wypełnić zobowiązanie lub realizować dążenie". Na podstawie definicji podejścia ukierunkowanego na działanie (zadaniowego) można określić najważniejsze składniki obecne w zadaniu stawianym przed uczącymi się. Zadanie takie pozwala na jednoczesne rozwijanie kompetencji ogólnych i językowych kompetencji komunikacyjnych. Podczas jego wykonywania uczący się powinni uaktywnić kompetencje strategiczne tak, by wybrać najwłaściwszy sposób rozwiązania postawionego przed nimi problemu. Uaktywnienie wymienionych kompetencji pozwala na podjęcie działania językowego 
w jednej z czterech sfer życia - uczący się rozumie i/lub tworzy teksty, uwzględniając kontekst związany z uwarunkowaniami i ograniczeniami sytuacyjnymi, powoli zmierza do określonego celu, chce jak najlepiej i najskuteczniej wykonać postawione przed nim zadanie (ESOKJ, 2003: 20).

Kategoria zadania/działania często pojawia się w badaniach nad dydaktyką języków obcych w kontekście interkulturowym. Torenc (2008: 236) posługuje się terminem działania międzykulturowego - w jej teorii to „wywieranie przez daną osobę wpływu na sytuację na podstawie jej osobistej wiedzy". Możemy zatem rozumieć, że kompetencji interkulturowej nie nabywa się mimowolnie i automatycznie, lecz poprzez określone działania uczącego się oraz nauczyciela. Aby rozwijać u studentów interkulturową kompetencję komunikacyjną, należy postawić przed nimi zadanie, które dzięki właściwemu zarysowaniu kontekstu sytuacyjnego stworzonego sztucznie w przestrzeni klasy, pozwoli uczącym się na zweryfikowanie własnych hipotez odnośnie inności kulturowej. Rozwijanie kompetencji międzykulturowej polegałoby na podejmowaniu wysiłków interpretujących i wyjaśniających określone sytuacje oraz na wskazaniu reguł i zasad kierujących własną interpretacją poprzez odwoływanie się do teorii osobistych. Porównując te dwie koncepcje - definicje ESOKJ oraz podejście psychologii międzykulturowej, widzimy ich wyraźną zbieżność. I w tym przypadku działanie stanowi element kluczowy; zadanie jest osadzone w kontekście społecznym, środowiskowym, sytuacyjnym. Uczącemu się towarzyszy silna motywacja i wyobrażenia związane z efektem końcowym jego pracy, gdzie centralny punkt stanowi sukces komunikacyjny w grupie, w celu osiągnięcia którego musi on uruchomić określone strategie.

\section{Model Davida Kolba a trening akulturacyjny oparty o metodę symulacji}

Autorki przywoływanego już podręcznika dla trenerów wykazują, że aby właściwie przygotować trening akulturacyjny wykorzystujący metodę symulacji, warto sięgnąć do badań Davida Kolba (1984 za Lipińska, 2008: 22-23). Badacz scharakteryzował cztery etapy składowe procesu efektywnego uczenia się, biorąc pod uwagę cztery style: empiryczny, analityczny, teoretyczny i pragmatyczny. Następnie powiązał każdy z nich z kolejnym etapem zajęć tak, by wszystkie zostały uwzględnione podczas jednej jednostki lekcyjnej. Kolejne style uczenia się oraz etapy lekcji w teorii Kolba to:

- etap planowania - odpowiadający stylowi pragmatycznemu, który jest zorientowany na postrzeganie związku między rozwiązaniem zadania a problemem; 
- etap działania i doświadczenia - odpowiadający stylowi empirycznemu, dla którego najefektywniejsze przyswajanie treści polega na uczeniu się przez działanie;

- etap oceny sytuacji i refleksji - odpowiadający stylowi analityka, dla którego najefektywniejsze jest uczenie się poprzez obserwację i ocenę skutków wykonywanego zadania;

- etap teorii i konkluzji - odpowiadający stylowi teoretyka, który uczy się najlepiej podczas prezentacji zagadnień teoretycznych czy konkretnych faktów.

W modelu Kolba realizacja wymienionych etapów daje możliwość efektywnej nauki wszystkim uczestnikom bez względu na prezentowany przez nich styl uczenia się.

\section{Syndromy kulturowe}

Podstawę psychologiczną dla tworzenia danego treningu stanowi zestaw syndromów (wymiarów) kulturowych, których definicja została już przywołana. Psychologia międzykulturowa dokonała ich podziału ze względu na ich charakter. Niniejszy tekst nie charakteryzuje wszystkich syndromów kulturowych nazwanych przez badaczy, ma na celu naświetlenie jedynie kilku wybranych. Kryterium selekcji stanowiła obecność tych wymiarów w propozycji zajęć treningowych, których scenariusz znajduje się w końcowej części niniejszego artykułu. W tym celu odwołujemy się do badań Geerta Hofstedego, holenderskiego psychologa społecznego, oraz Richarda Gestelanda, trenera warsztatów międzykulturowych specjalizującego się w komunikacji i negocjacjach podczas interesów międzynarodowych.

Hofstede (2000: 96-97) wyróżnia pięć głównych wymiarów kultur narodowych; jednym z nich jest opozycja kultur indywidualistycznych i kolektywistycznych. Dla kultur indywidualistycznych jednostka stanowi podstawę społeczeństwa, obecne jest silne i stanowcze „ja”, które przejawia się zarówno w jej postępowaniu, jak i sposobie narracji o świecie. Dominują indywidualistyczne cele życiowe: najwyżej cenione jest poczucie niezależności, autonomia, prywatność, poczucie kontroli, rozwój osobisty i kariera. Charakter więzi pomiędzy ludźmi ocenia się jako luźny, jednostka może przynależeć jednocześnie do wielu grup. W porozumiewaniu się istotna jest jasność komunikatów oceniana na podstawie środków werbalnych. Inaczej rysują się kultury kolektywistyczne - nad jednostką góruje pojęcie grupy, ,ja” jest współzależne od innych członków zespołu, w narracji o świecie dominuje kategoria „my”. Najważniejsze są cele i wartości kolektywu - solidarność, harmonia, współpraca, współodpowiedzialność, przestrzeganie norm grupowych. W komunikacji istotny jest 
kontekst oraz niewerbalne środki wyrazu (Strelau i Doliński, 2004: 426). Według badań Hofstedego główne kraje indywidualistyczne to: Stany Zjednoczone, Australia, Wielka Brytania, Kanada i Holandia, natomiast kolektywistyczne to: Gwatemala, Ekwador, Panama, Wenezuela, Tajwan i Korea Południowa (Hofstede, 2000: 129).

Gesteland (2000: 58) poddał obserwacji osobiste doświadczenia praktyk i zwyczajów stosowanych podczas transakcji biznesowych przez przedstawicieli różnych kultur i na ich podstawie zaproponował kategoryzację opartą o system wspólnych zachowań. Jedną z jego propozycji jest relacja kultur monochronicznych i polichronicznych, która łączy się ze stosunkiem do pojęcia czasu. Kultury monochroniczne cechuje większe przywiązanie do punktualności i nieprzekraczalności ustalonych wcześniej dat. Typowy jest dla nich niezmienny porządek dnia, podlegający pod ustalony wcześniej plan, w przeciwieństwie do kultur polichromicznych, które preferują luźny harmonogram i nie troszczą się o terminowość. Konflikty pojawiające się pomiędzy tymi kulturami wynikają przede wszystkim z niewłaściwego odczytania intencji zachowań rozmówców. Za szczególnie niegrzeczne, oznakę braku szacunku i ignorancję jest uważana przez kultury monochroniczne niepunktual ność, podobne odczucia cechują przedstawicieli kultur polichromicznych, którzy nie zgadzają na narzucanie sztywnych terminów i odbierają taki sposób zachowania jako protekcjonalny, lekceważący i pogardliwy (tamże: 67).

\section{Zajęcia treningowe - budowa}

Powyższe obserwacje posłużyły do przygotowania propozycji zajęć o charakterze praktycznym, przeznaczonych dla uczących się języka polskiego jako obcego na poziomie B1/B2, przechodzących z jednej kultury do drugiej, których celem jest zbliżenie poziomu efektywności funkcjonowania w nowej kulturze do poziomu funkcjonowania w kulturze rodzimej. W tworzeniu prezentowanego treningu wzięto pod uwagę treści Programów nauczania języka polskiego jako obcego. Poziomy A1-C2 (Janowska i in., 2011), uwagę skupiono na katalogu tematycznym, funkcjonalno-pojęciowym, propozycji ról komunikacyjnych oraz katalogu zagadnień socjolingwistycznych, socjokulturowych i realioznawczych.

Uzyskanie postawy relatywizmu kulturowego jest kluczowe dla przeprowadzenia udanej symulacji. Stanowi ona jeden z głównych celów metody treningowej, a zarazem klucz do dalszych, stałych zmian. Trudność wynika z samej definicji oraz z kontekstu nauczania języka polskiego jako obcego, a mianowicie - heterogenicznego charakteru grup lektoratowych. Odpowiedzią na ten problem jest metoda treningowa bazująca na pracy na modelach kultur określonych jako X, Y, Z (może być to również oznaczenie poprzez wykorzystanie 
kolorów, np. grupa zielona, żółta, czerwona, czy według innego, nienacechowanego emocjonalnie schematu), gdzie symbole stanowią wybrane syndromy kulturowe charakterystyczne dla różnych grup, warunkowane uznanymi przez nie wartościami. Ten zabieg pozwala na rozpoczęcie pracy bez uprzedzeń ze strony biorących udział w warsztacie.

Budowę treningu rozpoczynamy niejako od końca. Najpierw wybieramy określoną krytyczną sytuację wziętą „z życia”, która będzie głównym punktem symulacji, następnie tłumaczymy ją na podstawie syndromów kulturowych w tym celu odwołujemy się do wybranych teorii psychologicznych, kolejnym etapem jest umiejscowienie danej sytuacji w zagadnieniach katalogów przywołanych powyżej. Całość projektujemy na podstawie modelu Davida Kolba. Propozycja scenariusza tego typu zajęć znajduje się poniżej.

\begin{tabular}{|c|c|}
\hline \multicolumn{2}{|r|}{$\begin{array}{l}\text { TRENING AKULTURACYJNY: } \\
\text { „TYLKO } 4 \text { MINUTY” }\end{array}$} \\
\hline & ec \\
\hline atalog funkcjonalno-pojęciowy: & $\begin{array}{l}\text { wyraża } \\
\text { trzeby }\end{array}$ \\
\hline ( & \\
\hline & relacje profesor - student, nauczyciel - uczeń, zachowanie na egzaminach \\
\hline \multicolumn{2}{|c|}{$\begin{array}{l}\text { Psychologiczne podstawy treningu: } \\
\text { Choć zegarki na całym świecie mają taki sam układ godzin na tarczy, poczucie czasu jest różne w zależności od kultury } \\
\text { Ten z pozoru błahy problem może być przyczyną wielu konfliktów i niepowodzeń w komunikacji pomiędzy przedsta- } \\
\text { wicielami odmiennych kultur, którzy reprezentują swoim zachowaniem zupełnie inne wartości. }\end{array}$} \\
\hline \multicolumn{2}{|c|}{ Zachowania i wartości związane z tym zagadnieniem: } \\
\hline \multicolumn{2}{|c|}{$\begin{array}{l}\text { Kultury monochroniczne cechuje przywiązanie do punktualności, nieprzekraczalności ustalonych wcześniej dat, } \\
\text { niezmienny porządek dnia, który podlega pod ustalony wcześniej plan. Jako szczególna niegrzeczność, oznaka } \\
\text { braku szacunku i ignorancja jest traktowana nawet drobna niepunktualność. }\end{array}$} \\
\hline \multicolumn{2}{|c|}{$\begin{array}{l}\text { - Kultury polichroniczne nie troszczą się o terminowość, preferują luźny harmonogram. Konflikty, które pojawiają się } \\
\text { w kontakcie z tego typu kulturami, wynikają z niewłaściwego odczytania intencji zachowań. Przedstawiciele tej kul- } \\
\text { tury opierają się narzucaniu sztywnych terminów i odbierają taki sposób traktowania jako zachowanie protekcjo- } \\
\text { nalne, lekceważące i pogardliwe. }\end{array}$} \\
\hline \multirow{2}{*}{\multicolumn{2}{|c|}{$\begin{array}{l}\text { Dla niniejszej symulacji istotny jest również podział na kultury indywidualistyczne i kolektywistyczne w warunkach } \\
\text { szkolnych. } \\
\text { - Kultury indywidualistyczne-celem edukacji jest przygotowanie ucznia-jednostki do życia w społeczeństwie złożo- } \\
\text { nym z innych jednostek. Stosunek do rzeczy nowych ma charakter pozytywny, często jest traktowany jako wyzwa- } \\
\text { nie. Nacisk kładziony jest na to, jak się czegoś nauczyć-liczy się zdolność rozwiązywania problemów, nie konkretne } \\
\text { umiejętności. W zamyśle tych kultur człowiek uczy się całe życie. Potrzeba kontaktu z nauczycielem jest duża. } \\
\text { - Kultury kolektywistyczne - celem edukacji jest zdobycie konkretnych umiejętności, nowe informacje przekazywane } \\
\text { są w formie instruktażu. W zamyśle tych kultur człowiek uczy się w określonym czasie po to, by sprawnie funkcjo- } \\
\text { nować w grupie. Potrzeba kontaktu z nauczycielem jest niewielka. }\end{array}$}} \\
\hline & \\
\hline \multicolumn{2}{|c|}{ achowanıa I wartosci typowe dla Polakow na tle powyzszych obserwacjl: } \\
\hline \multicolumn{2}{|c|}{$\begin{array}{l}\text { Polska sytuuje się bliżej kultur indywidualistycznych, jednocześnie można określić jajjako kulturę polichroniczną, która } \\
\text { w sytuacjach nieoficjalnych (czasem oficjalnych) pozwala na drobne lub większe spóźnienia. W kontaktach z przed- } \\
\text { stawicielami kultury polskiej można pozwolić sobie na spóźnienia w granicy } 15 \text { minut lub na dłuższe - jeśli będą od- } \\
\text { powiednio uzasadnione i wytłumaczone. }\end{array}$} \\
\hline
\end{tabular}




\begin{tabular}{|c|c|}
\hline Cele: & $\begin{array}{l}\text { - wprowadzenie uczestników symulacji w tematykę komunikacji międzykulturo- } \\
\text { wej; } \\
\text { - stworzenie motywacji do wykorzystywania własnych doświadczeń w zajęciach; } \\
\text { - przegląd zjawisk obecnych w komunikacji międzykulturowej istotnych dla te- } \\
\text { matu symulacji: wyrażanie pojęć ogólnych - relacje czasowe; } \\
\text { - rozwój kompetencji komunikacyjnej przy braku dostatecznej kompetencji mię- } \\
\text { dzykulturowej; } \\
\text { - umiejętność radzenia sobie w sytuacjach trudnych i kryzysowych związanych z } \\
\text { brakiem dostatecznie rozwiniętej kompetencji międzykulturowej }\end{array}$ \\
\hline Materiały: & $\begin{array}{l}\text { - kolorowe karteczki w dwóch kolorach do podziału na dwie grupy; } \\
\text { - małe karteczki (samoprzylepne); } \\
\text { - tablica }\end{array}$ \\
\hline Czas trwania: & około 45 minut \\
\hline \multicolumn{2}{|c|}{ PRZEBIEG TRENINGU } \\
\hline \multicolumn{2}{|c|}{$\begin{array}{l}\text { 2. Losowy podział uczestników na dwie grupy poprzez wyciągnięcie kolorowych kartek, następnie losowy dobór w } \\
\text { pary-ma mieć charakter obiektywny, nie może zależeć ani od prowadzącego, ani od uczestników. } \\
\text { 3. Zarysowanie sytuacji: instrukcje są prezentowane w oddzielnych grupach tak, by członkowie przeciwnych grup } \\
\text { nie znali swoich zasad działania: grupa nauczycieli - prowadzą ważny egzamin, grupa uczniów - spóźnili się na } \\
\text { egzamin tylko } 4 \text { minuty, jest to dla nich niewiele, nawet tego nie zauważyli, nie widzą problemu i nie rozumieją, } \\
\text { dlaczego nauczyciel nie chce ich przyjąć na egzamin. } \\
\text { 4. Zasady panujące podczas symulacji: grupa nauczycieli - reprezentują kulturę kolektywistyczną oraz monochro- } \\
\text { niczną, grupa uczniów - reprezentują kulturę indywidualistyczną oraz polichroniczną. }\end{array}$} \\
\hline \multicolumn{2}{|c|}{$\begin{array}{l}\text { 5. Połączeni w pary uczest } \\
\text { przebieg symulacji, zach } \\
\text { 6. } 2 \text { minuty przed końcem } \\
\text { 7. Zakończenie symulacji. }\end{array}$} \\
\hline \multicolumn{2}{|c|}{$\begin{array}{l}\text { 8. Grupy nauczycieli i uczniów pracują oddzielnie. Członek każdej grupy pisze na małych kartkach propozycje odpo- } \\
\text { wiedzi na pytanie: jacy oni są? (jedna odpowiedź na jednej karteczce) oraz zastanawia się, jak czuła się na po- } \\
\text { czątku, w trakcie i na końcu, jakie uczucia jej towarzyszyły. } \\
\text { 9. Rozpoczyna się wspólne omówienie - w kręgu lub przy wspólnym stole. Należy podkreślić, że zbierane są do- } \\
\text { świadczenia grupy, a nie konkretnych uczestników. } \\
\text { 10. Uczniowie prezentują swoje obserwacje, przyczepiając kartki do tablicy - grupują je, dzięki czemu widać, które } \\
\text { propozycje pojawiały się najczęściej, następnie to samo robią nauczyciele. }\end{array}$} \\
\hline \multicolumn{2}{|c|}{$\begin{array}{l}\text { 11. Uczniowie ujawniają swoje zasady, następnie nauczyciele opisują typowe dla nich zachowania i to, z jakich war- } \\
\text { tości istotnych dla ich kultury one wypływały. }\end{array}$} \\
\hline \multicolumn{2}{|c|}{$\begin{array}{l}\text { 12. Uczniowie prezentują emocje, jakie towarzyszyły im podczas symulacji, następnie robią to nauczyciele. Po zakoń- } \\
\text { czeniu prezentacji określają, jak odebraliby odmienne zachowania, gdyby wcześniej rozumieli ich pochodzenie. }\end{array}$} \\
\hline \multicolumn{2}{|c|}{$\begin{array}{l}\text { (prezentacja właściwości kultur kolektywistycznych i indywidualistycznych oraz polichronicznych i monochronicz- } \\
\text { nych oraz ważnych dla nich wartości; podanie konkretnych przykładów takich krajów oraz charakterystyka i } \\
\text { umiejscowienie Polski i Polaków na ich tle). }\end{array}$} \\
\hline \multicolumn{2}{|c|}{$\begin{array}{l}\text { 14. Prowadzący prosi uczestników o prezentację własnych doświadczeń. Pyta, czy kiedyś mieli problem z taką lub } \\
\text { podobną sytuacją, czy z racji swojego pochodzenia - innego niż kraj przyjmujący - zostali potraktowani inaczej. } \\
\text { Mogą również odnieść się do podobnych sytuacji w ich kraju rodzimym. }\end{array}$} \\
\hline
\end{tabular}

Tabela 1: Propozycja scenariusza treningu akulturacyjnego (opracowanie własne). 


\section{Wnioski dla glottodydaktyki}

Niniejsze rozważania niosą ze sobą kilka obserwacji, które wydają się być przydatne dla glottodydaktyki.

Dotychczas brakowało narzędzi, które umożliwiłyby realizację celu, jakim jest rozwój interkulturowej kompetencji komunikacyjnej poprzez wykonywanie zadań. W ostatnich latach psychologia międzykulturowa dostarczyła wielu nowych propozycji, które można wykorzystać na gruncie dydaktyki języków obcych. Staraliśmy się pokazać, że adaptacja treningu akulturacyjnego opartego o metodę symulacji na potrzeby zajęć językowych jest uzasadniona i może sprzyjać rozwijaniu interkulturowej kompetencji komunikacyjnej.

Nie jest powiedziane, że trening akulturacyjny można zastosować do każdego tematu i każdej lekcji, nie jest to również wskazane. Warto jednak przewidzieć kilka takich treningów w toku całego kursu, co będzie miało korzystny wpływ nie tylko na osiągnięcia językowe na poziomie komunikacji z rodzimymi użytkownikami języka docelowego i innych języków, ale też na całe życie i wszelkie kontakty społeczne uczących się.

Należy zatem przeprowadzić badania wśród obcokrajowców uczących się języka polskiego podczas pobytu w Polsce, mające na celu wskazanie konkretnych sytuacji krytycznych, w których sukces komunikacyjny w kontakcie z rodzimymi użytkownikami języka polskiego został zachwiany lub nie powiódł się. Chodzi tutaj o przywołanie zdarzeń, w których poziom porozumienia werbalnego zwiastował sukces, jednak mimo to nie został on osiągnięty, a dla uczestników była to sytuacja szczególnie niejasna, rażąco dziwna i kłopotliwa. Tego typu zdarzenie może zostać wyjaśnione przez pryzmat odmiennych syndromów kulturowych typowych dla rozmówców, a w przyszłości posłużyć w przygotowaniu zajęć zorientowanych na rozwój interkulturowej kompetencji komunikacyjnej uczących się.

\section{BIBLIOGRAFIA}

Boski, P. 2010. Kulturowe ramy zachowań społecznych. Podręcznik psychologii międzykulturowej. Warszawa: Wydawnictwo Naukowe PWN.

Chaves, R.-M., Favier, L. i S. Pélissier. 2012. L'interculturel en classe. Grenoble: Presses universitaires de Grenoble.

Europejski System Opisu Kształcenia Językowego: uczenie się, nauczanie, ocenianie. 2003. Warszawa: Wydawnictwa CODN

Gesteland, R. 2000. Różnice kulturowe a zachowania w biznesie. Warszawa: Wydawnictwo Naukowe PWN.

Grzymała-Moszczyńska, H. 2004: „Jak można się uczyć innej kultury - treningi akulturacyjne dla studentów". (w) Tolerancja i wielokulturowość - wyznania XXI wieku. (red. A. Borowiak i P. Szarota). Warszawa: Wydawnictwo SWPS Academica, str. 177-189. 
Hofstede, G. 2000. Kultury i organizacje: zaprogramowanie umysłu. Warszawa: Polskie Wydawnictwo Ekonomiczne.

Janowska, I., Lipińska, E., Rabiej, A., Seretny, A. i P. Turek (red.). 2011. Programy nauczania języka polskiego jako obcego. Poziomy A1-C2. Kraków: Księgarnia Akademicka.

Lipińska, M. (red.). 2008. Warsztaty kompetencji międzykulturowych-podręcznik dla trenerów. Warszawa: Uniwersytet Warszawski.

Siek-Piskozub, T. 1995. Gry, zabawy i symulacje w procesie glottodydaktycznym. Poznań: Wydawnictwo Naukowe UAM.

Strelau, J. i D. Doliński (red.). 2004. Psychologia: podręcznik akademicki. Gdańsk: Gdańskie Wydawnictwo Psychologiczne.

Torenc, M. 2000: „Międzykulturowość jako wyzwanie dla nauczycieli języków obcych”. (w) Kultury i języki. Poznawać - uczyć się - nauczać. (red. A. Jaroszewska i M. Torenc). Warszawa: Uniwersytet Warszawski, str. 233-240. 